\title{
Glucagon-like peptide-1 profile during oral glucose tolerance test in young people
}

\section{ABSTRACT}

Introduction. Currently, a major social problem is the occurrence of insulin resistance and metabolic disorders, which are risk factors for the development of type 2 diabetes. Particularly disturbing are the reports of an increasing number of such disorders in young people. The carbohydrate metabolism is regulated by neurohormonal mechanisms and insulin plays a major role in maintaining glucose homeostasis. Its secretion is determined by the current glucose concentration and the action of incretin hormones. The incretin effect describes the phenomenon whereby oral glucose elicits higher insulin secretory response than does the same intravenous glucose administration. This effect is visibly defective in patients with carbohydrate metabolism disorders.

Objective. The aim of the study was to analyse the glucagon-like peptide 1 (GLP-1) concentration profile during the extended (three-point) oral glucose tolerance test (OGTT) and to assess its relationship to OGTT curve shape after $\mathbf{7 5} \mathbf{g}$ glucose load and presence or absence of metabolic syndrome (MS) features in young, potentially healthy individuals.

Material and methods. The study group consisted of 53 volunteers (40 women and 13 men) aged 19-28 years, with normal fasting blood glucose and normal glucose tolerance. Body mass, waist circumference,

Address for correspondence:

dr Sylwia Płaczkowska

Diagnostyczne Laboratorium Naukowo-Dydaktyczne

Wydział Farmaceutyczny z Oddziałem Analityki Medycznej

Uniwersytet Medyczny, Wrocław

ul. Borowska 211A, 50-556 Wrocław

e-mail: sylwia.placzkowska@umed.wroc.pl

Translation: lek. Małgorzata Kamińska

Clinical Diabetology 2017, 6, 5, 151-158

DOI: $10.5603 /$ DK.2017.0026

Received: 10.05.2017

Accepted: 12.11 .2017 blood pressure, glucose, insulin, triglycerides, total and HDL cholesterol, GLP-1 and hsCRP concentrations were measured in the fasting state. Glucose, insulin and GLP-1 levels were also measured at 60 and 120 min after oral administration of $75 \mathrm{~g}$ of glucose. The results were analysed in subgroups based on the time required to return to fasting levels of blood glucose and the number of identified features of MS.

Results. Comparison of the results obtained in the fasting state and at 60 and $120 \mathrm{~min}$ of the extended OGTT showed no significant differences in glucose and GLP-1 concentrations, whereas fasting plasma insulin concentrations were significantly lower than those observed at 60 and $120 \mathrm{~min}$ of the OGTT. Neither the time for blood glucose to return to fasting values nor the number of metabolic syndrome features were associated with significant differences in GLP-1 concentrations between the groups analysed at any of the measurement points (fasting state, 60 and $120 \mathrm{~min}$ of the OGTT). Only the tendency to lower GLP-1 values was observed in the group of patients with the MS. Conclusions. Our observations may suggest that GLP-1 level measurements are not useful in determining the insulin response profile after glucose oral administration in young people without apparent carbohydrate disorders, but they may indicate disturbances in the incretin effect in subjects with MS. Our study will be continued with a larger number of volunteers to provide a more detailed mechanism of the regulation of insulin secretion by incretins and the potential role of GLP-1 in the development of MS in young people. (Clin Diabetol 2017; 6, 5: 151-158)

Key words: glucagon-like peptide-1, oral glucose tolerance test, metabolic syndrome, young people, insulin resistance 


\section{Introduction}

The carbohydrate metabolism is regulated by neurohormonal mechanisms and the main role in maintaining glucose homeostasis is played by insulin, the secretion of which is determined by the current glucose concentration and the action of incretin hormones, such as glucagon-like peptide-1 (GLP-1) and glucose-dependent insulinotropic peptide (GIP). Incretin hormones are components of the intestinal-pancreatic axis and play an important role in postprandial increase in insulin secretion by $\beta$-cells of the pancreas. These hormones are responsible for the so-called 'incretin effect', which consist in a significantly stronger insulin response to oral intake of glucose-containing food than to the same amount of glucose administered intravenously $[1,2]$. Meal ingestion stimulates L-cells of the mucous membrane of the small intestine to synthesise and secrete incretin hormones that reach the pancreatic $\beta$-cells through the blood vessels and stimulate insulin secretion even before the glucose concentration in the intercellular fluid of the pancreatic is increased [3].

The glucagon-like peptide- 1 acts by linking to specific GLP-1R receptors that are located on pancreatic islet cells, as well as in the digestive system, kidneys, lungs, blood vessels, heart and brain. In the pancreas, GLP-1 stimulates $\beta$-cells to insulin synthesis by inducing expression of the corresponding gene [4]. In addition, it has the ability to stimulate the proliferation and differentiation of $\beta$-cells and protects them against apoptosis [5]. The glucagon-like peptide- 1 exerts a hypoglycaemic effect also by inhibiting glucagon secretion from the pancreas and delaying the passage of gastrointestinal content from the stomach to the small intestine. Oral administration of glucose results in a greater and faster GLP-1 secretion than taking a mixed solid meal [6]. Of particular importance is the fact that GLP-1 stimulates insulin secretion mainly in hyperglycaemic state and has negligible insulinotropic effect on pancreatic $\beta$-cells in the state of normoglycaemia, which prevents from hypoglycaemia [7]. The increase in GLP-1 concentration is observed in both lean and obese patients after a meal or oral glucose load [8]. Reduction of the incretin, i.e. decreased GLP-1 secretion with normal GIP secretion, is observed in subjects with concomitant impaired fasting glycaemia (IFG) and impaired glucose tolerance (IGT) and in patients with type 2 diabetes [9].

Recent studies point out the increasingly high prevalence of insulin resistance and metabolic disorders in populations of industrialized countries [10], and particularly alarming are the reports indicating the occurrence of these disorders in an increasing number of young people [11]. The problem is all the more important because many of them are not aware of their condition and do not undergo regular prophylactic examinations [12]. The basis for the diagnosis of carbohydrate metabolism abnormalities remains the two-point oral glucose tolerance test (OGTT), which nevertheless does not show the dynamics of blood glucose changes. Recent reports, however, highlight the usefulness of blood glucose measurements at several OGTT time points in detecting carbohydrate disorders [13]. Data from the literature show that in subjects with blood glucose values in the fasting state and at $120 \mathrm{~min}$ of the OGTT suggestive of lack glucose metabolism abnormalities the glycaemic curve may have different shapes depending on the ability to release insulin and tissue sensitivity to insulin. It is estimated that the incretin effect is responsible for up to $70 \%$ for postprandial insulin secretion [14].

In the available literature there are only scarce data on changes in the GLP-1 profile during the OGTT $[8,15,16]$ and its relation to the presence of a variable number of features determining the diagnosis of metabolic syndrome (MS). However, there are no studies that refer to changes in GLP-1 levels depending on the time required for return of blood glucose values to fasting level and the shape of the curve. Both of these parameters, i.e. the rate of blood glucose fall in the postabsorptive state and the presence of MS features, are closely related to the severity of insulin resistance of tissues. In this aspect, the analysis of GLP-1 profile in the course of the extended (three-point) OGTT in young, potentially healthy people and the assessment of relationship between GLP-1 and the presence or absence of MS features in this group seems interesting.

\section{Material and methods}

The study group consisted of 53 volunteers ( 40 women and 13 men) aged 19-28 years. Participation in the study was voluntary and the approval of the Bioethics Committee at the Medical University of Wrocław (KB No. 194/2009) was obtained. A questionnaire survey, as well as anthropometric, clinical and laboratory examinations were performed in all participants. The physical examination included basic anthropometric (height, body weight, waist circumference) and blood pressure measurements. Laboratory tests included measurements of blood glucose, insulin, GLP-1, lipid profile (total cholesterol, HDL cholesterol and triglyceride levels were measured, LDL cholesterol level was calculated) and high-sensitivity C-reactive protein (hsCRP) were determined. Patients with good overall health, without hyperglycaemia in the fasting state or after glucose load, who had not been previously diagnosed with MS, met the inclusion criteria. Exclusion criteria included a history of glucose intolerance 
or diabetes, hypertension or taking antihypertensive drugs, hypercholesterolaemia or taking lipid-lowering drugs, liver or kidney failure. In addition, excluded from the participation in the study were also people with a history of cancer, those who had acute infections during the 2 weeks preceding the study or were taking antiallergic drugs during the 3 months preceding the study. Additional exclusion criteria were fasting blood glucose $\geq 126 \mathrm{mg} / \mathrm{dL}$, serum hsCRP protein level $\geq 10 \mathrm{mg} / \mathrm{L}$ and peripheral blood leukocyte count $\geq 10.0 \mathrm{G} / \mathrm{L}$.

The OGTT was performed in accordance with the recommendations of the Diabetes Poland [17], with a modification of taking an additional blood sample at $60 \mathrm{~min}$ after glucose load. Laboratory tests were performed on venous blood samples collected during the three-point 75-g OGTT, i.e. in the fasting state and at 60 and $120 \mathrm{~min}$ of the test. Fasting venous blood samples were collected using a Sarstedt Monovette closed system (Germany) to 3 tubes: two containing EDTA-K3 and another one containing a clot activator. In the whole-blood sample, complete blood counts were performed, while glucose and GLP-1 levels were measured in plasma. Serum lipid profile, insulin and hsCRP were also determined. In the samples taken at 60 and 120 min of the test, plasma glucose and GLP-1 as well as serum insulin were measured. Biochemical assays were made using the Konelab 20i biochemical analyser (ThermoScientific, USA). Peripheral blood counts were performed using the Cell-Dyn 1800 haematology analyser (Abbott, USA). The insulin concentration was determined by immunoenzymatic reagent kit from DRG Diagnostics (Germany) and the concentration of GLP-1 was determined by immunoenzymatic method (Yanaihara Institute Inc., Japan) using MR-96A microplate reader (Mindray, China).

\section{Statistical analysis}

Statistical analysis of the obtained results was performed using Statistica 12, PL software package (StatSoft, USA). Measurement results are presented as median with $25-75 \%$ range of observed values (lower and upper quartile) and minimum and maximum values. For all continuous variables, the normality of the distribution was assessed using the Shapiro-Wilk test. The Kruskal-Wallis ANOVA for independent variables and Friedman's ANOVA for dependent variables were used for the comparative analysis of the results. In all tests used, observed differences were considered statistically significant at $p<0.05$.

\section{Results}

First, anthropometric, clinical and biochemical parameters were analysed, taking into account the participants' gender, as shown in Table 1. Physiologically significant higher levels of HDL cholesterol were found in women; whereas men had significantly higher waist circumferences. In addition, men were characterized by significantly higher systolic blood pressure and triglycerides.

Table 2 summarizes the values of blood glucose, insulin and GLP-1 measured in the fasting state and at 60 and $120 \mathrm{~min}$ of the OGTT in the examined group of young people together with the statistical analysis. Distribution of fasting and 60- and 120-min post-load GLP-1 levels in the study group is shown in Figure 1.

The analysis of the results obtained in the fasting state and at 60 and $120 \mathrm{~min}$ of the extended OGTT did not show any significant differences in glucose and GLP-1 levels. In contrast, fasting insulinaemia was significantly lower than the values obtained at 60 and $120 \mathrm{~min}$ of the OGTT.

Next, the profile of changes in GLP-1 concentrations during the extended OGTT was analysed in subgroups defined on the basis of differences in the time required for blood glucose to return to fasting values during the OGTT. The analysis was carried out in three groups designated as 1, 2 and 3, respectively. Group 1 consisted of 26 people whose blood glucose returned to fasting levels before $60 \mathrm{~min}$ of the OGTT. Group 2 included 13 people whose blood glucose returned to fasting levels between 60 and $120 \mathrm{~min}$ of the OGTT. Group 3 consisted of 13 people in whom blood glucose did not return to fasting values before $120 \mathrm{~min}$ of the OGTT. The results of this analysis are presented in Table 3.

In none of the analysed groups $(1,2,3)$ defined on the basis of the time for blood glucose to return to fasting values, significant changes were found when analysing fasting and post-load concentrations of GLP-1. However, it was observed that GLP-1 levels at 60 and $120 \mathrm{~min}$ of the OGTT decreased with increase in time required to return to fasting values of blood glucose. The results analysed within a given group were characterized only by a downward trend compared with the fasting levels, and in each group the lowest values were observed at $60 \mathrm{~min}$ of the OGTT. There were no significant differences in the GLP-1 concentration between the analysed groups at individual OGTT measurement points. The most evident trend toward decrease in GLP-1 levels at individual measurement points was found in group 3, but these changes were not statistically significant.

In the next stage of the analysis, the study participants were divided into groups (marked as I, II and III respectively) depending on the number of MS features. The features of metabolic syndrome were identi- 
Table 1. Anthropometric parameters, lipid profile, inflammatory markers and blood pressure in the whole examined group and men and women analysed separately

\begin{tabular}{|c|c|c|c|c|}
\hline Parameter & $\begin{array}{l}\text { All patients } \\
\quad(n=53)\end{array}$ & $\begin{array}{l}\text { Women } \\
(n=40)\end{array}$ & $\begin{array}{c}\text { Men } \\
(n=13)\end{array}$ & $p$ \\
\hline \multirow[t]{3}{*}{ Age (years) } & 22 & 22 & 23 & 0.056 \\
\hline & $(21-23)$ & $(21-23)$ & $(21-24)$ & \\
\hline & $(19-28)$ & $(19-26)$ & $(20-28)$ & \\
\hline \multirow[t]{3}{*}{ Waist circumference $[\mathrm{cm}]$} & 79 & 76 & 86 & 0.001 \\
\hline & $(72-83)$ & $(72-82)$ & $(82-96)$ & \\
\hline & $(65-107)$ & $(65-92)$ & $(76-107)$ & \\
\hline \multirow[t]{3}{*}{ Total cholesterol [mmol/L] } & 4.1 & 4.1 & 4.2 & 0.914 \\
\hline & $(3.8-4.7)$ & $(3.9-4.7)$ & $(3.8-4.6)$ & \\
\hline & $(3.3-7.4)$ & $(3.5-6.2)$ & $(3.3-7.4)$ & \\
\hline \multirow[t]{3}{*}{ HDL cholesterol [mmol/L] } & 1.4 & 1.5 & 1.0 & 0.000 \\
\hline & $(1.2-1.6)$ & $(1.3-1.6)$ & $(1.0-1.2)$ & \\
\hline & $(0.8-2.3)$ & $(1.0-2.3)$ & $(0.8-1.4)$ & \\
\hline \multirow[t]{3}{*}{ Triglycerides [mmol/L] } & 0.9 & 0.8 & 1.0 & 0.044 \\
\hline & $(0.6-1.4)$ & $(0.6-1.2)$ & $(0.8-1.7)$ & \\
\hline & $(0.4-2.6)$ & $(0.4-2.2)$ & $(0.7-2.6)$ & \\
\hline \multirow[t]{3}{*}{ Systolic blood pressure [mm Hg] } & 110 & 109 & 116 & 0.008 \\
\hline & $(105-120)$ & $(103-119)$ & $(110-125)$ & \\
\hline & $(90-140)$ & $(90-140)$ & $(110-140)$ & \\
\hline \multirow[t]{3}{*}{ Diastolic blood pressure [mm Hg] } & 71 & 70 & 77 & 0.136 \\
\hline & $(70-80)$ & $(70-80)$ & $(70-80)$ & \\
\hline & $(55-90)$ & $(55-90)$ & $(70-90)$ & \\
\hline \multirow[t]{3}{*}{ Leukocytes [G/L] } & 6.3 & 6.2 & 6.5 & 0.441 \\
\hline & $(5.5-7.2)$ & $(5.5-7.1)$ & $(6.0-7.9)$ & \\
\hline & $(3.4-8.9)$ & $(3.4-8.9)$ & $(4.5-8.3)$ & \\
\hline \multirow[t]{3}{*}{ hsCRP [mg/L] } & 0.73 & 0.90 & 0.54 & 0.104 \\
\hline & $(0.31-1.65)$ & $(0.32-2.43)$ & $(0.01-0.82)$ & \\
\hline & $(0.01-9.85)$ & $(0.01-9.85)$ & $(0.01-1.06)$ & \\
\hline
\end{tabular}

Results are presented as median with $25-75 \%$ range of observed values (lower and upper quartile) and minimum and maximum values

Table 2. Values of blood glucose, insulin and GLP-1 levels in the fasting state and at 60 and $120 \mathrm{~min}$ of the OGTT in all examined persons

\begin{tabular}{|c|c|c|c|c|}
\hline \multirow[t]{2}{*}{ Parameter } & \multicolumn{3}{|c|}{ Oral glucose tolerance test } & \multirow[t]{2}{*}{ p } \\
\hline & Fasting state & $60 \mathrm{~min}$ & $120 \mathrm{~min}$ & \\
\hline \multirow[t]{3}{*}{ Glucose $[\mathrm{mmol} / \mathrm{L}]$} & 5.0 & 5.3 & 5.0 & NS \\
\hline & $(4.8-5.3)$ & $(4.3-6.3)$ & $(4.3-5.9)$ & \\
\hline & $(4.2-5.5)$ & $(3.0-8.5)$ & $(2.5-6.9)$ & \\
\hline \multirow[t]{3}{*}{ Insulin $[\mu \mathrm{IU} / \mathrm{mL}]$} & 11.0 & 49.0 & 37.2 & $<0.001$ \\
\hline & $(8.6-13.9)$ & $(28.8-67.9)$ & $(27.6-56.9)$ & \\
\hline & $(2.9-30.9)$ & $(12.3-166.9)$ & $(7.2-94.5)$ & \\
\hline \multirow[t]{3}{*}{ GLP-1 [ng/mL] } & 6.14 & 5.28 & 5.99 & NS \\
\hline & $(4.50-7.93)$ & $(4.28-7.06)$ & $(4.57-7.59)$ & \\
\hline & $(2.74-29.65)$ & $(1.33-34.00)$ & $(2.60-32.20)$ & \\
\hline
\end{tabular}

Results are presented as median with $25-75 \%$ range of observed values (lower and upper quartile) and minimum and maximum values 


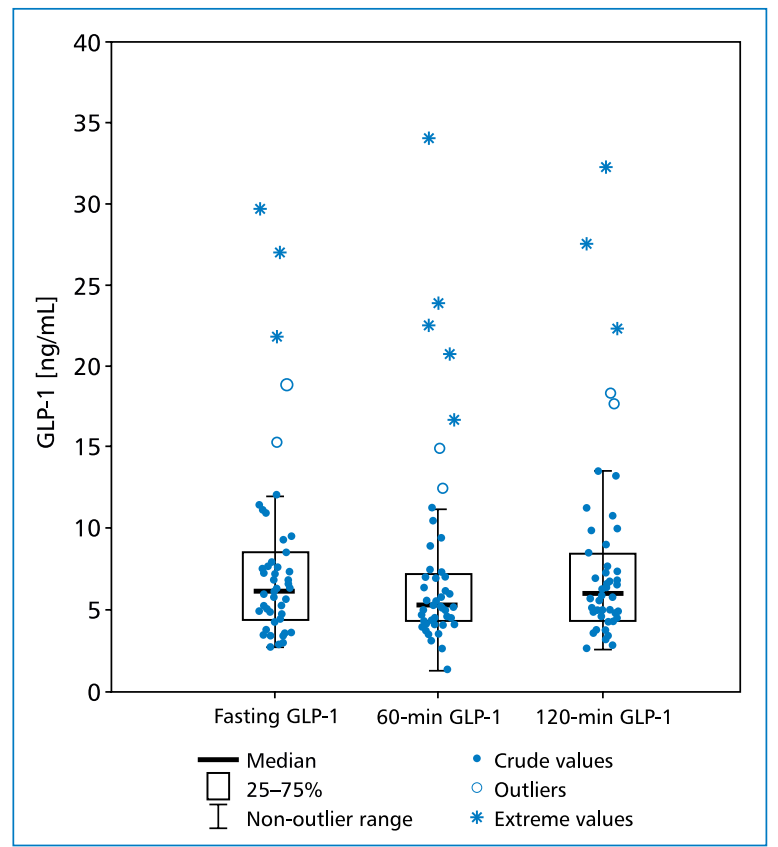

Figure 1. Distribution of GLP-1 concentrations measured in the fasting state and at 60 and $120 \mathrm{~min}$ of the OGTT in all participants of the study fied based on the International Diabetes Federation (IDF) 2009 criteria, i.e., waist circumference $\geq 80 \mathrm{~cm}$ for women and $\geq 94 \mathrm{~cm}$ for men, triglycerides $\geq 1.7 \mathrm{mmol} / \mathrm{L}, \mathrm{HDL}$ cholesterol $<1.3 \mathrm{mmol} / \mathrm{L}$ for women and $<1.0 \mathrm{mmol} / \mathrm{L}$ for men, systolic blood pressure $\geq 130 \mathrm{~mm} \mathrm{Hg}$ and/or diastolic blood pressure $\geq 80 \mathrm{~mm} \mathrm{Hg}$, and fasting blood glucose $\geq 5.5 \mathrm{mmol} / \mathrm{L}$. Metabolic syndrome was diagnosed if at least three of the above five features were present [18].

The participants of the study were assigned to the following three groups: group I included 26 people who did not have any feature of MS; group II included 23 people who had 1 or 2 features of MS; group III included 4 people with MS identified based on the results of the examinations performed. The values of GLP-1 concentrations measured during the OGTT (in the fasting state and at 60 and 120 after glucose load) were analysed in each group. The results of the analysis are presented in Table 4.

In none of the analysed groups (I, II, III) defined on the basis of the number of MS features, statistically significant changes between the fasting and post-load concentration of GLP-1 were found during the OGTT.

Table 3. Analysis of GLP-1 values at individual OGTT points according to the time taken to return to fasting blood glucose values during the OGTT

\begin{tabular}{|c|c|c|c|c|}
\hline \multirow{2}{*}{$\begin{array}{ll}\text { Measurement points } & \text { Groups } \\
\end{array}$} & Group 1 & Group 2 & Group 3 & \multirow[t]{2}{*}{$\mathbf{p}^{*}$} \\
\hline & $<60 \min \mathrm{OGTT}$ & $60-120 \mathrm{~min}$ OGTT & $>120 \mathrm{~min}$ OGTT & \\
\hline \multirow[t]{2}{*}{ Fasting GLP-1 [ng/mL] } & 6.65 & 5.24 & 6.44 & \multirow[t]{2}{*}{ NS } \\
\hline & $(4.85-11.16)$ & $(3.70-7.72)$ & $(4.39-7.66)$ & \\
\hline \multirow[t]{2}{*}{ GLP-1 at $60 \mathrm{~min}$ of OGTT $[\mathrm{ng} / \mathrm{mL}]$} & 6.12 & 5.11 & 4.52 & \multirow[t]{2}{*}{ NS } \\
\hline & $(5.00-9.36)$ & $(4.24-7.04)$ & $(4.01-5.58)$ & \\
\hline \multirow[t]{2}{*}{ GLP-1 at $120 \mathrm{~min}$ of OGTT $[\mathrm{ng} / \mathrm{mL}]$} & 6.31 & 5.20 & 4.76 & \multirow[t]{2}{*}{ NS } \\
\hline & $(4.68-9.36)$ & $(4.29-7.01)$ & $(4.85-5.59)$ & \\
\hline$p^{* *}$ & NS & NS & NS & \\
\hline
\end{tabular}

$\mathrm{p}^{*}$ - comparison of GLP-1 concentrations between groups at a specific OGTT measurement point; $\mathrm{p}^{* *}$ — comparison of GLP-1 concentrations between individual OGTT measurement points within one group. Results are presented as median with $25-75 \%$ range of observed values (lower and upper quartile)

Table 4. GLP-1 values at individual OGTT points according to the number of MS features

\begin{tabular}{|c|c|c|c|c|}
\hline \multirow{2}{*}{$\begin{array}{ll}\text { Measurement points } & \text { Groups } \\
\end{array}$} & Group I & Group II & Group III & \multirow[t]{2}{*}{$\mathbf{p}^{*}$} \\
\hline & (no feature of MS) & (1-2 features of MS) & (diagnosed MS) & \\
\hline \multirow[t]{2}{*}{ Fasting GLP-1 [ng/mL] } & 6.65 & 6.08 & 4.79 & \multirow[t]{2}{*}{ NS } \\
\hline & $(4.85-11.16)$ & $(4.65-8.93)$ & $(3.88-6.25)$ & \\
\hline \multirow[t]{2}{*}{ GLP-1 at $60 \mathrm{~min}$ of OGTT $[\mathrm{ng} / \mathrm{mL}]$} & 5.89 & 5.27 & 4.84 & \multirow[t]{2}{*}{ NS } \\
\hline & $(4.52-8.9)$ & $(4.28-7.09)$ & $(4.08-5.27)$ & \\
\hline \multirow[t]{2}{*}{ GLP-1 at $120 \mathrm{~min}$ of OGTT $[\mathrm{ng} / \mathrm{mL}]$} & 6.13 & 6.25 & 4.89 & \multirow[t]{2}{*}{ NS } \\
\hline & $(4.57-10.01)$ & $(3.70-7.36)$ & $(4.76-5.77)$ & \\
\hline$p^{* *}$ & NS & NS & NS & \\
\hline
\end{tabular}

$\mathrm{p}^{*}$ - comparison of GLP-1 concentrations between groups at a specific OGTT measurement point; $\mathrm{p}^{* *}$ — comparison of GLP-1 concentrations between individual OGTT measurement points within one group. Results are presented as median with $25-75 \%$ range of observed values (lower and upper quartile) 


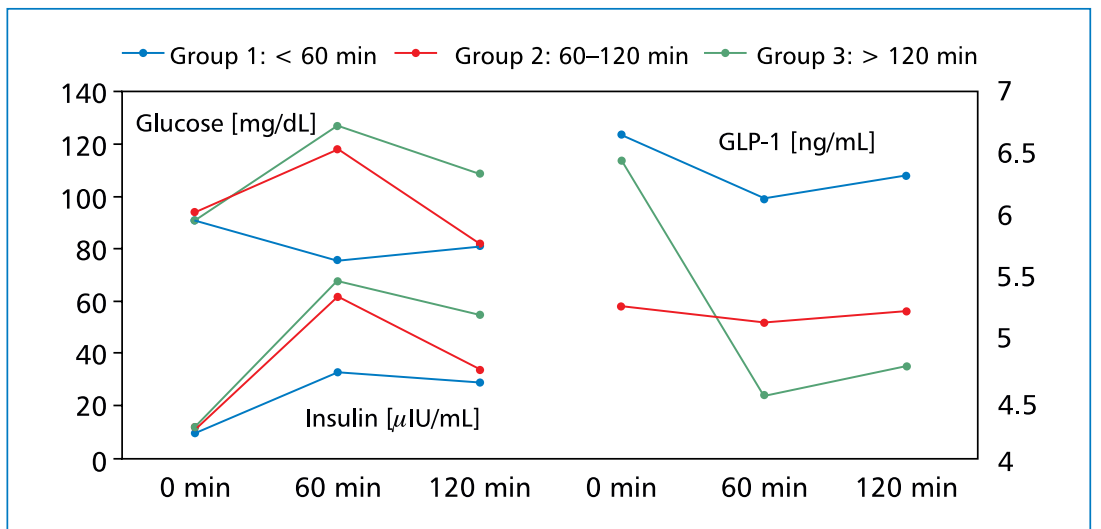

Figure 2. Median glucose, insulin and GLP-1 levels during the OGTT in groups $(1,2,3)$ defined on the basis of the time required for blood glucose to return to fasting values

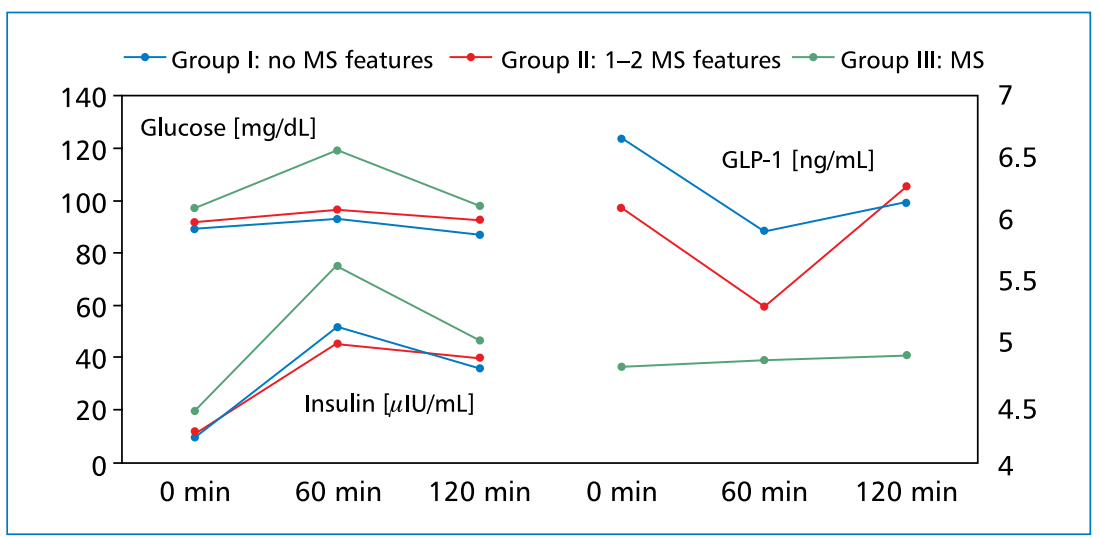

Figure 3. Median glucose, insulin and GLP-1 levels during the OGTT in groups (I, II, III) defined on the basis of the number of MS features

Only the downward trend in GLP-1 concentration was observed along with the increase in the number of MS features, and the lowest values were recorded in the group of people with diagnosed MS. There were no differences in the concentration of GLP-1 within the analysed groups at individual OGTT measurement points.

Changes in glycaemia, insulinaemia and GLP-1 concentration during the OGTT, presented as medians of the analysed parameters in individual groups distinguished on the basis of the time required for blood glucose to return to fasting values (groups 1, 2, 3) and the identified number of MS features (groups I, II, III) are depicted in Figure 2 and Figure 3, respectively.

\section{Discussion}

Glycaemic values observed after food intake or glucose load in the OGTT are the resultant of many factors, among which the most important are the rate of glucose utilization by peripheral tissues, pancreatic $\beta$-cell efficiency to secrete insulin as well as secretion and activity of incretin hormones related to the rate of gastrointestinal passage. These factors determine not only the magnitude of post-load change in blood glucose, but also the shape of the glycaemic curve and the time when the lowest and highest levels of blood glucose are observed [19, 20]. Glycaemic values measured in the fasting state and after glucose load in the OGTT are a useful predictor of diabetes development in the future, and indirectly may also be useful in predicting MS due to the insulin resistance underlying the development of this disorder [21]. The San Antonio Heart Study showed that people with normal fasting glucose and normal OGTT result whose blood glucose values failed to return to fasting levels during the OGTT had an increased risk of developing diabetes in the future compared with those whose glycaemia returned to fasting values within 30,60 or $120 \mathrm{~min}$ [22]. The only study regarding GLP-1 concentration at various 
measuring points in the three-hour OGTT was carried out by Velasquez-Mieyer et al. [15] in a group of obese, otherwise healthy people, including among others Caucasians subjects. The curve illustrating changes in GLP-1 levels (in pmol/L) presented in this paper shows that there are no significant differences between values measured at different time points during the OGTT, which is consistent with our results (showed in $\mathrm{ng} / \mathrm{mL}$ ).

It is very difficult to refer to the GLP-1 values from various studies because, even though commercially available ELISA assays are calibrated against the standards with the same concentration ranges (from 0 to $50)$, the concentration units $(\mathrm{ng} / \mathrm{mL}, \mathrm{pg} / \mathrm{mL}$ or $\mathrm{pmol} / \mathrm{L}$ ) are different $[15,16,23,24]$. Recalculation leads to ambiguous results, making it impossible to compare the absolute values obtained by different authors. Discrepancies in the measured concentrations of GLP-1 may be due to the lack of standardization of standards used to calibrate reagent kits for measuring GLP-1 level. For this reason, our analysis was limited to comparing changes in the GLP-1 profile during the OGTT.

In the analysed group of young people without carbohydrate metabolism disorders, no significant changes in GLP-1 concentration were found in any of the three measuring points of the extended OGTT. However, we observed significantly lower blood glucose values, especially at $60 \mathrm{~min}$ of the OGTT, compared to data from the literature [8]. Considering the small changes in glucose concentration during the OGTT in our study, it cannot be ruled out that a significant increase in GLP-1 concentration could take place within 10-30 minutes of glucose loading, and rapid glucose uptake into peripheral tissues in people with normal metabolism carbohydrate prevented further stimulation of GLP-1 secretion. In addition, the rapid degradation of this incretin, occurring under the influence of dipeptidyl peptidase IV (DPP-4), could result in the lack of a dynamic change in GLP-1 concentration in the observation based on measurements made at 60-minute intervals.

Analysis of GLP-1 concentrations in connection with the presence of a variable number of MS features in young, potentially healthy people also did not show significant changes in the specified groups. At none of the OGTT measurement points was there any relationship between the GLP-1 concentration and the number of MS features, indicating that there is no such dependence among the examined young subjects, although the incretin release is reduced in MS [25]. However, there was a downward trend in the concentration of GLP-1 in people diagnosed with MS compared to the other two groups, which may be related to the deterioration of carbohydrate-lipid disorders along with the appearance of other features of MS. Different observa- tions were made by Yamaoka et al. [26] who indicated a higher concentration of GLP-1 in patients with MS, but these studies concerned the Japanese population of 50-year-olds. Our observations require further study involving a larger number of young people, because MS was identified only in 4 participants of this study, which is why it has a pilot nature.

\section{Conclusions}

The results presented in this paper are interesting due to the fact that both literature data and the results of our previous studies $[12,27,28]$ indicate an increasing number of young people who are diagnosed with various types of metabolic disorders, which in the future may increase the prevalence of MS and type 2 diabetes. The potential contribution of reduced release of incretins in the stage of pre-diabetes is important in the development of metabolic disorders. However, there are no significant differences between fasting GLP-1 levels and the levels of this incretin measured during the OGTT in subjects with normal fasting glycaemia and normal glucose tolerance. These observations indicate that GLP-1 level measurements are not useful for interpreting the insulin response profile after glucose oral administration in young people without apparent carbohydrate disorders, but they may be helpful in the assessment of MS development in this group of patients $[26,29]$. Our study will be continued with a larger number of volunteers to provide a more detailed picture of the regulation of insulin secretion by incretins and the potential role of GLP-1 in the development of MS in young people.

\section{REFERENCES}

1. Matuszek B, Lenart-Lipinska M, Nowakowski A. Incretin hormones in the treatment of type 2 diabetes. Part I: influence of insulinotropic gut-derived hormones (incretins) on glucose metabolism. Endokrynol Pol. 2007; 58(6): 522-528.

2. Marathe CS, Rayner CK, Jones $\mathrm{KL}$, et al. Glucagon-like peptides 1 and 2 in health and disease: a review. Peptides. 2013; 44: 75-86, doi: 10.1016/j.peptides.2013.01.014, indexed in Pubmed: 23523778.

3. Bodnaruc AM, Prud'homme D, Blanchet R. Nutritional modulation of endogenous glucagon-like peptide-1 secretion: a review. Nutr Metab. 2016; 13(92), doi: 10.1186/s12986-016-0153-3.

4. Holst JJ. The physiology of glucagon-like peptide 1. Physiol Rev. 2007; 87(4): 1409-1439, doi: 10.1152/physrev.00034.2006, indexed in Pubmed: 17928588.

5. Cornu M, Thorens B. GLP-1 protects $\beta$-cells against apoptosis by enhancing the activity of an IGF-2/IGF1-receptor autocrine loop. Islets. 2009; 1(3): 280-282, doi: 10.4161/isl.1.3.9932, indexed in Pubmed: 21099285.

6. Yamane S, Harada N, Hamasaki A, et al. Effects of glucose and meal ingestion on incretin secretion in Japanese subjects with normal glucose tolerance. J Diabetes Investig. 2012; 3(1): 80-85, doi: 10.1111/j.2040-1124.2011.00143.x, indexed in Pubmed: 24843549 . 
7. Kieffer T, Habener JF. The Glucagon-Like Peptides. Endocr Rev. 1999; 20(6): 876-913, doi: 10.1210/edrv.20.6.0385, indexed in Pubmed: 10605628 .

8. Muscelli E, Mari A, Casolaro A, et al. Separate impact of obesity and glucose tolerance on the incretin effect in normal subjects and type 2 diabetic patients. Diabetes. 2008; 57(5): 1340-1348, doi: $10.2337 / \mathrm{db} 07-1315$, indexed in Pubmed: 18162504

9. Zhang F, Tang X, Cao H, et al. Impaired Secretion of Total Glucagon-like Peptide-1 in People with Impaired Fasting Glucose Combined Impaired Glucose Tolerance. Int J Med Sci. 2012; 9(7): 574-581, doi: 10.7150/ijms.4128, indexed in Pubmed: 22991496.

10. Zdrojewski T, Rutkowski M, Bandosz $P$, et al. Rozpowszechnienie i kontrola czynników ryzyka sercowo-naczyniowego w Polsce. Cele i sposób realizacji badania NATPOL 2011. Kardiol Pol. 2013; 71(4): 381-392, doi: 10.5603/kp.2013.0066, indexed in Pubmed: 23788344.

11. Wirtualny magazyn Pielęgniarki i Położnej. Diagnoza stanu zdrowia Polaków według NATPOL 2011. http://www.nursing.com. pl/Aktualnosci_Diagnoza_stanu_zdrowia_Polakw_wedug_NATPOL_2011_1006.html (02.02.2017).

12. Płaczkowska S, Pawlik-Sobecka L, Kokot I, et al. [Incidence of complex metabolic disorders among young people - preliminary report]. Pol Merkur Lekarski. 2014; 37(221): 269-273, indexed in Pubmed: 25546987.

13. Otto-Buczkowska E, Dryżałowski M. Użyteczność pomiaru glikemii w pierwszej godzinie doustnego testu tolerancji glukozy. Diabetologia Praktyczna. 2016; 4(2): 146-149.

14. Salehi M, Aulinger B, D'Alessio DA. Effect of Glycemia on Plasma Incretins and the Incretin Effect During Oral Glucose Tolerance Test. Diabetes. 2012; 61(11): 2728-2733, doi: 10.2337/db111825, indexed in Pubmed: 22733799.

15. Velasquez-Mieyer PA, Umpierrez GE, Lustig RH, et al. Race affects insulin and GLP-1 secretion and response to a long-acting somatostatin analogue in obese adults. International Journal of Obesity. 2004; 28(2): 330-333, doi: 10.1038/sj.ijo.0802561, indexed in Pubmed: 14708034.

16. Wang $X L$, Ye F, Li J, et al. Impaired secretion of glucagon-like peptide 1 during oral glucose tolerance test in patients with newly diagnosed type 2 diabetes mellitus. Saudi Med J. 2016; 37(1): 48-54, doi: 10.15537/smj.2016.1.12035, indexed in Pubmed: 26739974.

17. Zalecenia kliniczne dotyczące postępowania u chorych na cukrzycę 2016 Stanowisko Polskiego Towarzystwa Diabetologicznego. Diabetologia Kliniczna. 2016; 5(Suplement A).

18. Alberti KG, Eckel RH, Grundy SM, et al. International Diabetes Federation Task Force on Epidemiology and Prevention, Hational Heart, Lung, and Blood Institute, American Heart Association, World Heart Federation, International Atherosclerosis Society, International Association for the Study of Obesity. Harmonizing the metabolic syndrome: a joint interim statement of the International Diabetes Federation Task Force on Epidemiology and Prevention; National Heart, Lung, and Blood Institute; American
Heart Association; World Heart Federation; International Atherosclerosis Society; and International Association for the Study of Obesity. Circulation. 2009; 120(16): 1640-1645, doi: 10.1161/ CIRCULATIONAHA.109.192644, indexed in Pubmed: 19805654.

19. Tschritter O, Fritsche A, Shirkavand F, et al. Assessing the Shape of the Glucose Curve During an Oral Glucose Tolerance Test. Diabetes Care. 2003; 26(4): 1026-1033, doi: 10.2337/diacare.26.4.1026, indexed in Pubmed: 12663568.

20. Abdul-Ghani MA, Matsuda M, Jani R, et al. The relationship between fasting hyperglycemia and insulin secretion in subjects with normal or impaired glucose tolerance. Am J Physiol Endocrinol Metab. 2008; 295(2): E401-E406, doi: 10.1152/ /ajpendo.00674.2007, indexed in Pubmed: 18492770.

21. Abdul-Ghani MA, DeFronzo RA. Plasma Glucose Concentration and Prediction of Future Risk of Type 2 Diabetes. Diabetes Care. 2009; 32(suppl_2): S194-S198, doi: 10.2337/dc09-s309, indexed in Pubmed: 19875551.

22. Abdul-Ghani MA, Williams K, DeFronzo R, et al. Risk of progression to type 2 diabetes based on relationship between postload plasma glucose and fasting plasma glucose. Diabetes Care. 2006; 29(7): 1613-1618, doi: 10.2337/dc05-1711, indexed in Pubmed: 16801587.

23. Pontikis C, Yavropoulou MP, Toulis KA, et al. The incretin effect and secretion in obese and lean women with polycystic ovary syndrome: a pilot study. J Womens Health (Larchmt). 2011; 20(6): 971-976, doi: 10.1089/jwh.2010.2272, indexed in Pubmed: 21671782.

24. Mannucci E, Ognibene A, Cremasco F, et al. Glucagon-like peptide (GLP)-1 and leptin concentrations in obese patients with Type 2 diabetes mellitus. Diabet Med. 2000; 17(10): 713-9, indexed in Pubmed: 11110504.

25. de Luis DA, Aller R, Conde R, et al. Basal glucagonlike peptide 1 levels and metabolic syndrome in obese patients. J Investig Med. 2012; 60(6): 874-877, doi: 10.2310/JIM.0b013e3182544f9e, indexed in Pubmed: 22534628.

26. Yamaoka-Tojo M, Tojo T, Takahira N, et al. Elevated circulating levels of an incretin hormone, glucagon-like peptide-1, are associated with metabolic components in high-risk patients with cardiovascular disease. Cardiovasc Diabetol. 2010; 9: 17, doi: 10.1186/1475-2840-9-17, indexed in Pubmed: 20470376.

27. Płaczkowska S, Kokot I, Pawlik-Sobecka L, et al. Indices of insulin resistance in Wroclaw university students - Preliminary report. Family Medicine and Primary Care Review. 2013; 15(3): 370-1.

28. Szostak-Wegierek D, Waskiewicz A. Metabolic disorders in women at procreative age living in Warsaw. Rocz Panstw Zakl Hig. 2015; 66(3): 245-51, indexed in Pubmed: 26400121.

29. Manco M, Panunzi S, Macfarlane DP, et al. One-Hour Plasma Glucose Identifies Insulin Resistance and Beta-Cell Dysfunction in Individuals With Normal Glucose Tolerance: Cross-sectional data from the Relationship between Insulin Sensitivity and Cardiovascular Risk (RISC) study. Diabetes Care. 2010; 33(9): 2090-2097, doi: 10.2337/dc09-2261, indexed in Pubmed: 20805281. 